\title{
Vital Signs Sequence Number
}

National Cancer Institute

\section{Source}

National Cancer Institute. Vital Signs Sequence Number. NCI Thesaurus. Code C83462.

An identifier that describes the relative position of vital signs data within a series. 